DOI 10.18551/rjoas.2019-11.24

\title{
THE EVALUATION OF RESIDUAL CHLORINE FROM WELL DRINKING WATER IN SOME QUARTERS IN ERBIL CITY OF NORTH IRAQ
}

\author{
Rabar Mohammed Hussein \\ Department of Basic Aquatic Sciences, Faculty of Fisheries, Fırat University, Elazig, Turkey \\ E-mail: rabarmohammad@yahoo.com
}

\begin{abstract}
The study was conducted in Erbil city north of Iraq. Everywhere in the world, the drinking water utilities face the challenge of providing water of good quality to their consumers as significant water quality changes can occur within drinking water distribution systems due to contamination. From this study, we have collected water samples from twenty well drinking waters in some quarters from Erbil City with three replicas. Our results showed that the maximum value of free chlorine recorded in (Badawa and Galawesh) quarters which were greater than 0.5 , while, the values of free chlorine of most quarters were less than 0.2 , which were not within the recommended safe residual chlorine level of $0.2-0.5 \mathrm{mg} / \mathrm{l}$.
\end{abstract}

\section{KEY WORDS}

Free chlorine, water consumer, drinking water, water well.

Across the globe, drinking water services face the challenge of providing good quality water to their consumers as significant changes in water quality can occur in drinking water systems due to contamination. A disinfectant such as chlorine can control the growth of pathogens but it reacts with organic and inorganic matter in water, the concentration of chlorine decreases with time, called chlorine decomposition. (Boccelli et al., 2003). Chlorine is a strong oxidant, it reacts with a wide range of chemicals and organic (and / or inorganic) materials naturally present in treated water and / or distributed to form potentially harmful disinfection by-products (DBP). . Some of these DBPs are suspected of being carcinogenic and have adverse effects on reproductive and developmental health (Shihab et al., 2009). It is essential for any water authority to manage chlorine disinfection in the lower and upper limits of residual chlorine in order to simultaneously protect consumers from waterborne diseases and harmful DBP. For example, residual chlorine concentration at various points in the drinking water distribution system may be considered as the last control of water quality provided to consumers. Due to the importance of disinfection, a number of investigators have conducted research to develop models to predict the decomposition of chlorine in drinking water (Clark, 2012).

It is easy to believe that the safety of modern drinking water treatment systems is secure, but before widespread filtration and chlorination, contaminated drinking water posed a significant risk to public health. Water-based microscopic agents such as cholera, typhoid fever, dysentery and hepatitis A have killed thousands of US residents each year before chlorine disinfection methods are increasingly used in Jersey. City, New Jersey(McGuire, 2013). Worldwide, at least 2 billion people use chronic diarrhea, cholesterol, dysentery, typhoid, hay fever and polio (WHO, 2017). Contaminated drinking water is estimated to cause more than 500,000 deaths each year, mostly among children. (WHO, 2018). Although developed countries have largely eliminated waterborne pathogenic bacteria through the use of chlorine and other disinfectants, the developing world is still struggling with these public health enemies (WHO, 2017). . Contamination of water resources by pathogens Chlorine is lost by reaction with substances left in the water after treatment, especially organic and inorganic substances such as iron, manganese or ammonia. Chlorine degradation therefore depends on the residence time (Vasconcelos et al., 1997). Chlorine infection, however, shows problems such as the production of trihalomethane (THM) from its reaction with Natural Organic Matter (NOM) in water (Alsheyab, 2006). The mechanisms and rates of decomposition of hypochloric acid $(\mathrm{HOCl})$ and hypochlorite ion $(\mathrm{OCl})$ depend on many 
factors including $\mathrm{pH}$, chemical concentration, solar radiation (UV), and temperature (Cotton and Wilkinson, 1988). In addition to decomposing free chlorine, UV radiation from solar radiation can also act as a strong disinfectant in removing pathogenic organisms from water because it destroys germs, viruses and other pathogens by inactivating their DNA (Acher, 1985). The main aim of this study is to evaluate residual chlorine in drinking water in Erbil City and to compare recommended chlorine levels (WHO).

The study was conducted in Erbil city north of Iraq which covers about 18170 square kilometres (Fig.1). It is bounded by greater Zap River from the North-West and by little zaps River from the South-East. Boundaries extended from longitude $4315 \mathrm{E}$ to $4514 \mathrm{E}$ and from latitude $3527 \mathrm{~N}$ to $3724 \mathrm{~N}$ (Hussein et.12019).

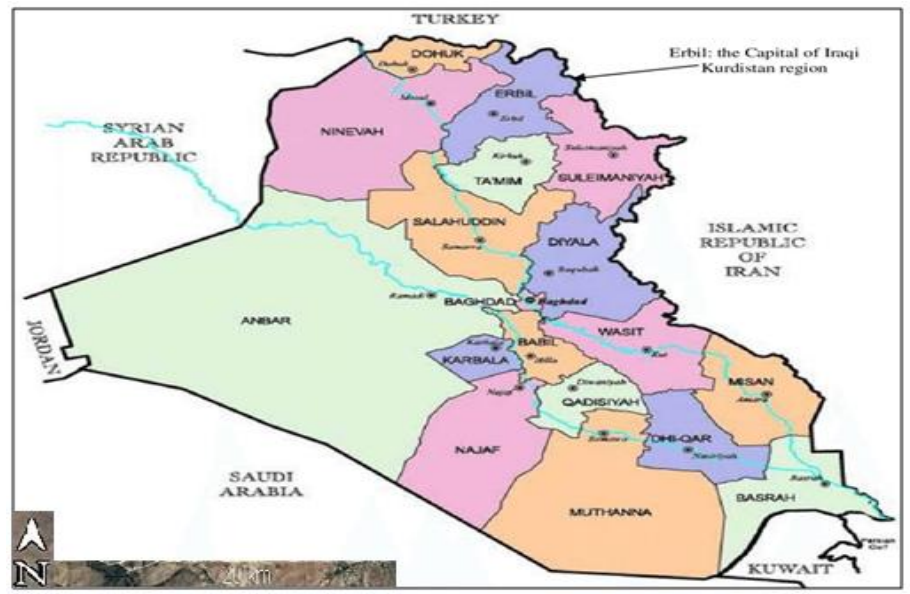

Figure 1 - Location of studied area (Iraq map) (Hussein, 2019)

\section{MATERIALS AND METHODS OF RESEARCH}

Water samples were taken from twenty wells in some quarters in Erbil city (Azadi, Zhyan, Topzawa, Ankawa, Harsham City, Runakey, Daratw, Rasty, Havalan,(32 park), Farmanba-ran, Kurany-Ankawa, Andazyaran-city, Zanko,Galagay rash, Hawlery-New, Shady, Mahabad, Badawa and Galawesh) with three replicas. Then, we analyzed free chlorine using (Pooltester, Germany) as shown in the figure (1). Then we compared our results with the recommended safe residual chlorine level of $0.2-0.5 \mathrm{mg} / \mathrm{l}(\mathrm{WHO}, 2008)$.

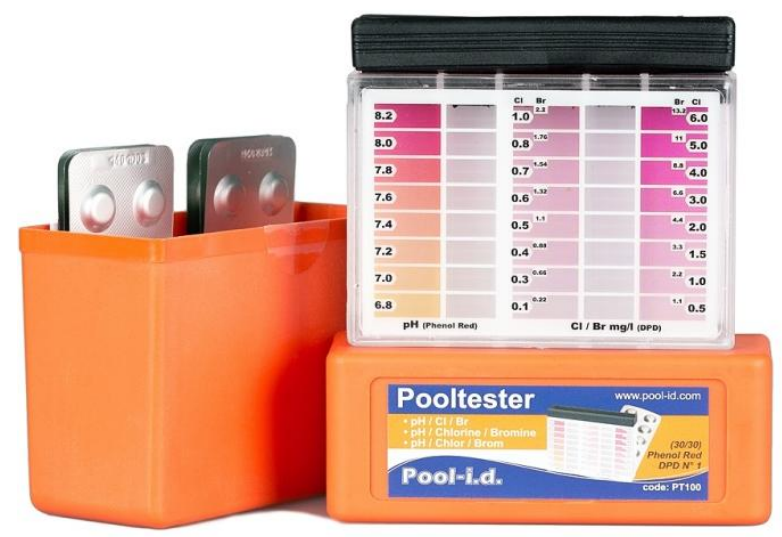

Figure 2 - Shows the pool water test kits (Source: www.water-id.com).

Statistical analysis was performed using a software program (SPSS version 18). All data were treated with the one-way ANOVA (Analysis of Variance), Post hoc test (Duncan) for detecting significant difference between variables at different sites. All data are expressed as mean \pm S.E. 


\section{RESULTS AND DISCUSSION}

Chlorine is such a strong oxidizer, it reacts with a wide range of chemicals and naturally occurring organic (and/or inorganic) matter (NOM) in the treated and/or distributed water to form potentially harmful disinfection by-products (DBPs). Some of these DBPs are suspected carcinogens and having adverse reproductive and developmental health effects (Shihab et al., 2009). The free chlorine values of the studied sites ranged from 0.1 to 1.07 $(\mathrm{mg} / \mathrm{l})$ between sites as shown in (Figure 2 and table 1). The minimum value of free chlorine recorded in (32 park), Bnaslawa, Andazyaran-city, Ankawa, Daratw, Harsham-City, Havalan, Hawlery-New,Kurany-Ankawa, Mahabad, Rasty, Shady, Topzawa) which were not within The recommended safe residual chlorine level of $0.2-0.5 \mathrm{mg} / \mathrm{l}(\mathrm{WHO}, 2008)$, is therefore not easily maintained in the distribution network and therefore increasing recontamination risk, also which may be related to water well operator to not add enough chlorine and not use scientifically method to treat with the chlorination process. Factors such as dissolved organic carbon, $\mathrm{Fe}^{2+}, \mathrm{Mn}^{2+}, \mathrm{NO}^{2-}, \mathrm{H}_{2} \mathrm{~S}, \mathrm{H}_{2} \mathrm{SO}_{3}$, ammonia, high temperatures and also corroded pipes, dead ends, long storage time (Gauthier et al., 2000), that can be attributed to low chlorine levels at the reservoirs and further depletions during conveyance in the very old pipes in the network. Several factors however influence chlorine decay in water distribution network (Trussell, 1999).

Table 1 - Mean \pm SE for parameters (according to the site of sampling) with minimum and maximum values

\begin{tabular}{|c|c|c|c|c|c|c|c|c|c|c|}
\hline Variable & Azadi & Zhyan & awazpoT & Ankawa & $\begin{array}{l}\text { Harsham- } \\
\text { City }\end{array}$ & Runakey & Daratw & Rasty & Havalan & (32 park) \\
\hline $\begin{array}{c}\text { Free } \\
\text { chlorine } \\
\text { (mg/L) }\end{array}$ & $\begin{array}{c}c b \\
0.30 \pm 0.05 \\
0.54-0.05\end{array}$ & $\begin{array}{c}\mathrm{B} \\
0.46 \pm \\
0.08 \\
0.84-0.08\end{array}$ & $\begin{array}{c}C \mathrm{C} \\
0.10 \pm 0.00 \\
0.10-0.10\end{array}$ & $\begin{array}{c}C \\
0.10 \pm 0.00 \\
0.10-0.10\end{array}$ & $\begin{array}{c}c c \\
0.10 \pm 0.00 \\
0.10-0.10\end{array}$ & $\begin{array}{c}\mathrm{b} \\
0.33 \pm 0.12 \\
0.85-0.18\end{array}$ & $\begin{array}{c}c c \\
0.10 \pm 0.00 \\
0.10-0.10\end{array}$ & $\begin{array}{c}c c \\
0.10 \pm 0.00 \\
0.10-0.10\end{array}$ & $\begin{array}{c}c c \\
0.10 \pm 0.00 \\
0.10-0.10\end{array}$ & $\begin{array}{c}c c \\
0.10 \pm 0.00 \\
0.10-0.10\end{array}$ \\
\hline $\begin{array}{c}\text { Free } \\
\text { chlorine } \\
\text { (mg/L) }\end{array}$ & $\begin{array}{c}c b \\
0.30 \pm 0.05 \\
0.54-0.05\end{array}$ & $\begin{array}{c}C \\
0.10 \pm 0.00 \\
0.10-0.10\end{array}$ & $\begin{array}{c}C \\
0.10 \pm 0.00 \\
0.10-0.10\end{array}$ & $\begin{array}{c}\mathrm{Cb} \\
0.26 \pm 0.03 \\
0.41-0.12\end{array}$ & $\begin{array}{c}c \\
0.10 \pm 0.00 \\
0.10-0.10\end{array}$ & $\begin{array}{c}c \\
0.10 \pm 0.00 \\
0.10-0.10\end{array}$ & $\begin{array}{c}c \\
0.10 \pm 0.00 \\
0.10-0.10\end{array}$ & $\begin{array}{c}c \\
0.10 \pm 0.00 \\
0.10-0.10\end{array}$ & $\begin{array}{c}a \\
1.06 \pm 0.23 \\
2.07-0.06\end{array}$ & $\begin{array}{c}a \\
1.00 \pm 0.00 \\
1.00-1.00\end{array}$ \\
\hline
\end{tabular}

Note: Values in each rows with different letters are significantly different at $P<0.05$. Values in rows with same letter are not significantly different.

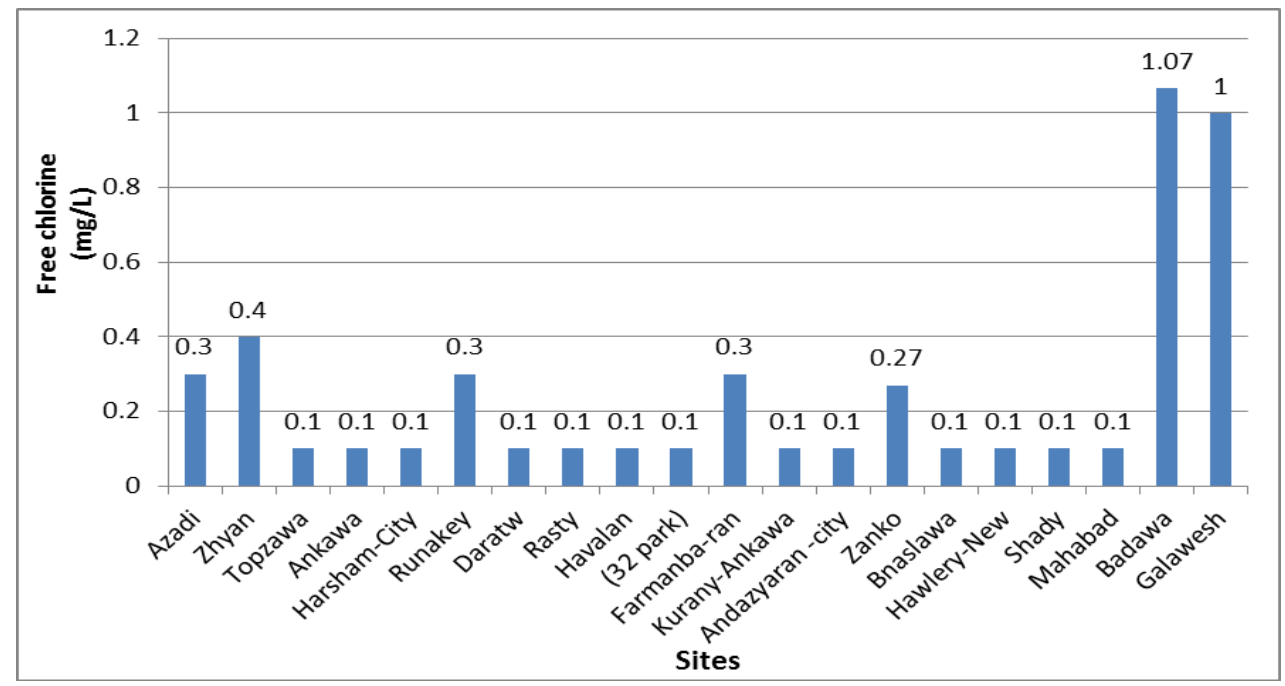

Figure (3): Shows the free Chlorine (mg/L) values at study sites

Where other, the maximum value recorded in (Galawesh and Badawa) as shown in (Figure 2 and table 1) which were greater than 0.5 not within the recommended safe residual chlorine level of $0.2-0.5 \mathrm{mg} / \mathrm{l}$ (WHO, 2008). Chlorine disinfection, however, shows problems such as the production of trihalomethane (THM) from its reaction with Natural Organic Matter (NOM) in water (Alsheyab, 2006). The mechanisms and rates of decomposition of hypochlorous acid $(\mathrm{HOCl})$ and hypochlorite ion $(\mathrm{OCl})$ are dependent on a number of factors 
including $\mathrm{pH}$, chemical concentration, solar radiation (UV), and temperature (Cotton and Wilkinson, 1988). (Zanko, Runakey, Azadi, Farmanba-ran and Zhyan) (Figure 2 and table 1), which were within the recommended safe residual chlorine level of $0.2-0.5 \mathrm{mg} / \mathrm{l}$ (WHO, 2008), this ensures microbiologically safe water.

Statistically, there were no significant differences $(p<0.05)$ between (Azadi,awazpoT, Ankawa, Harsham-City, Daratw, Rasty, Havalan, (32 park), Farmanba-ran, Kurany-Ankawa, Andazyaran-city, Zanko, Bnaslawa, Hawlery-New, Shady and Mahabad) quarters (Table 1). While, (Badawa and Galawesh) quarters were significant differences $(p<0.05)$ in compared to other sites (Table 1), which were greater than 0.5 not within the recommended safe residual chlorine level of $0.2-0.5 \mathrm{mg} / \mathrm{l}$ (WHO, 2008), which may be related to water well operator to use more chlorine and not use scientifically method to treat with the chlorination process, and not good concern from the Government.

\section{CONCLUSION}

In conclusion, we have noticed that (Badawa and Galawesh) quarters had maximum value of free chlorine which was greater than 0.5 while the values of free chlorine of most quarters were less than 0.2. We recommend that chlorine concentration should be maintained between 0.2 and $0.5 \mathrm{mg} / \mathrm{l}$ throughout the water distribution network, also, the well water operator should be well trained to treat with the chlorination process, checking pump systems and daily routine tests will be required monthly.

\section{REFERENCES}

1. Acher, A .J. Sunlight photooxidation of organic pollutants in wastewater (1985). Water Science and Technology, 17, pp.623-632.

2. Alsheyab, M.A. (2006). Reducing the formation of trihalomethanes (THMs) by ozone combined with hydrogen peroxide (H2O2/O3). Desalination, 194, pp.121-126.

3. Boccelli DL (2003). A reactive species model for chlorine decay and THM formation under rechlorination conditions. Water Res 37: 2654-2666.

4. Carrico B, Singer PC (2009). Impact of booster chlorination on chlorine decay and THM production: simulated analysis. J Environ Eng ASCE 135 (10):928-935.

5. Clark R M. (2012). Water quality modeling. American Water Works Association, USA.

6. Cotton, F.A. and Wilkinson, G. (1988). Advanced Inorganic Chemistry, Fifth Edition, John Wiley and Sons, New York.

7. Gauthier,V.; Besner M-G; Barbeau, B; Millette, R and Prèvost, M. (2000). Storage tank management to improve drinking water quality: Case study. J.Water.Resour.PIng. and Mgmt.126 (4): 221-228. https://www.water-id.com/html/index.php

8. Mc Guire, M.J. (2013). The Chlorine Revolution: Water Disinfection and the Fight to Save Lives. AWWA: Denver, Colorado.

9. Shihab MS (2009) Simulation of Chlorine concentrations in Mosul University's Distribution Network using EPANET program. J Al-Rafidain Eng 17(6):28-41.

10. Trussell, R.R., (1999). An Overview of Disinfectant Residuals in Drinking Water Distribution Systems, J. Water SRT - Aqua. 48 (1): 2-10.

11. Vasconcelos, J. J., Rossman, L. A., Grayman, W. M., Boulos, P. F. and Clark, R. M. (1997). "Kinetics of chlorine decay." Journal AWWA, 89(7), 54-65.

12. WHO (2017). Guidelines for Drinking-water Quality, 4th Edition, Incorporating the 1st Addendum. WHO Press: Geneva, Switzerland.

13. WHO (2018). Drinking-water Fact Sheet [Online]. Available: http://www.who.int/newsroom/fact-sheets/ detail/drinking-water (accessed 10-9-18).

14. World Health Organization, Centers for Disease Control and Prevention. de Benoist B, McLean E, Egli I, Cogswell M, eds. Worldwide prevalence of anemia 1993-2005. Geneva, World Health Organization, 2008.

15. Hussein (2019). Phycolimnological Study on Water Bodies of Two Major Parks in Erbil Province (North Iraq). Fresenius Environmental Bulletin.8858-8864. 